\title{
A CONSIDERATION OF COLOSTRUM AND MILK AS SOURCES OF ANTIBODIES WHICH MAY BE TRANSFERRED TO THE NEWBORN BABY
}

\author{
BY

\begin{abstract}
KATHLEEN E. BOORMAN, BARBARA E. DODD and MAVIS GUNTHER
From the South London Transfusion Centre, the Department of Forensic Medicine, London Hospital Medical College, and the Obstetric Hospital, University College Hospital, London
\end{abstract}

(RECEIVED FOR PUBLICATION JULY 19, 1957)

The fact that antibodies can be conveyed to a newborn animal by colostrum was first shown by Ehrlich (1892). In his experiments artificial antibodies to abrin and ricin were induced in mice; after exchange of litters of immunized and nonimmunized animals, the litters suckled from immunized mothers had acquired some measure of protection to abrin and ricin. Although the antibodies of colostrum are known to be absorbed unaltered by the newborn calf and lamb (Mason, Dalling and Gordon, 1930), there has been no clear evidence that such absorption occurs in human beings. If it does occur it is of less significance and is harder to detect because the baby, unlike a calf or lamb, is endowed before birth with maternal antibodies which it receives transplacentally. Thus the maternal serum, and therefore the infant's serum, will contain antibodies of the same specificity as the colostrum. When the baby is fed by its mother, absorption from the colostrum can be recognized only by an increase of the antibodies already in the baby's serum.

The question of absorption, even in small quantities, of unaltered antibodies is of importance, although the effects of depriving the child of colostrum or breast milk are not dramatic as in ungulates. We need to know what qualities or substances in breast milk contribute to the baby's defences and make the incidence of infection lower than among the bottle-fed. The lower incidence of gastro-enteritis among breast-fed babies (Douglas, 1950) could be explained by postulating less exposure to infection, but Douglas also found a significant protection against measles conferred by suckling. This protection showed a correlation with the length of lactation and lasted longer. The finding suggested that over a long period of breast feeding small amounts of globulin or antibody are absorbed or derived from the milk, or alternatively that breast milk influences the baby's hormonal or other control of its own antibodies. The widespread belief in the benefit of breast milk for premature babies conforms with the idea of antibody transfer, since the serum globulin is low in premature infants (Rimington and Bickford, 1946). If the protection which milk confers depends on the absorption of unaltered antibodies, heat treatment of breast milk should be avoided so far as is possible. If, on the other hand, the globulins of colostrum and milk are broken down in digestion and yet contribute to the baby's specific immunity, they do so presumably by providing the material for the rebuilt globulins, and heat treatment might be expected to have little or no effect. The possibility of absorption of unaltered antibodies is also of more direct and obvious importance in deciding whether an Rh-negative mother with $\mathrm{Rh}$ antibodies in her serum, colostrum and milk should feed her Rh-positive infant from the breast, or whether this would increase the severity of the haemolytic disease of the newborn from which it was already suffering.

In the investigation described here the anti-A and anti-B content of maternal serum, colostrum and milk, and of infant's serum taken at birth and at 3 and 10 days post partum, was determined. This was done in order to find the range of titration values and whether there was any correlation between them, for instance, whether a high titre of agglutinins in the maternal serum is associated with a high titre of the same agglutinins in the colostrum and milk, and whether the agglutinins of colostrum and milk pass unaltered through the digestive tract of the infant and appear in its serum. It was hoped in this way to measure the contribution of maternal antibodies which might be expected in completely normal physiological circumstances when any other effects such as the antitryptic effect of colostrum would be in full play. The question also 
arose whether the agglutinins might cause or prolong haemolytic disease of the newborn.

In the second part of the study a number of Rh-negative babies were bottle-fed with fluids containing anti-D antibodies and their sera examined at intervals for the appearance of these antibodies.

\section{Serological Methods}

The ABO grouping and $\mathrm{Rh}$ typing of maternal and cord samples was by the standard tube technique. The $A B O$ grouping included tests on the cells and serum of each individual.

Titration of Antibodies. The anti-A and anti-B agglutinins were titrated in the maternal serum taken at the time of delivery, in the colostrum on the third day and in the milk on the tenth day. In the infant the anti-A and anti-B agglutinins of the cord serum were titrated, also those of serum obtained by heel prick on the third and tenth days after birth.

The method used for titration of antibodies in serum was essentially as described by Taylor and Ikin (1939). Doubling dilutions of test serum were made in saline with a Pasteur pipette graduated to deliver a constant volume (about $0.03 \mathrm{ml}$.). To each of the dilutions an equal volume of a $2 \%$ suspension of appropriate red cells was added, the cells being always from the same donors and freshly drawn each day. The titrations were made in duplicate and allowed to stand at room temperature for two to three hours, after which the contents of the tubes were examined for agglutination both macroscopically and microscopically. The presence of evenly distributed clumps of three or more cells was accepted as evidence of agglutination. The titre of a serum sample was expressed as the reciprocal of the highest dilution of serum causing agglutination.

The maternal colostrum and milk were titrated in exactly the same way as the serum. It was, however, found necessary to centrifuge these fluids rapidly for five minutes so that the cream could be removed from the surface and discarded. Colostrum and milk also agglutinated Group $\mathrm{O}$ cells but the titration value was low; however, a titration against Group $O$ cells was included for each sample (see also Hirszfeld and LilleSzyszkowicz, 1949).

Complete or saline-agglutinating $\mathrm{Rh}$ antibodies were titrated in a similar way, but were incubated at $37^{\circ} \mathrm{C}$. instead of at room temperature. Owing to the fragile nature of the agglutinates, great care was taken in handling the contents of each tube when reading the tests. The standard red cells used were of the genotypes $R_{1} R_{1}(C D e C D e)$ and $R_{2} r$ (cDEcde), together with $r r$ (cdecde) as a negative control.

For the titration of incomplete or albumin-agglutinating $\mathrm{Rh}$ antibodies a slightly modified technique was used. The serial dilutions of the serum being tested were made in $\mathrm{AB}$ serum instead of saline and an equal volume of a $2 \%$ suspension of standard red cells in bovine albumin was added to each tube. The same precautions were taken in reading the tests.
Detection of Rh Antibodies. Four techniques were employed for the detection of anti-Rh (anti-D) antibodies in the baby's serum.

(a) Saline Technique. Equal volumes of the serum to be tested and a $2 \%$ suspension of standard cells were incubated for two hours and then the red cells were examined microscopically for agglutination, the $\mathrm{Rh}$ genotypes of the cells used being the same as those for the titration of saline agglutinins.

(b) Albumin Technique. Equal volumes of serum and a $2 \%$ suspension of red cells made in $30 \%$ bovine albumin were incubated for two hours and the tests read in the same manner as for the saline technique. For this test the standard cells used were of genotypes $R_{1} R_{2}$ (CDecDE) and $\mathrm{rr}$ (cdecde).

(c) INDIRECT COOMBS TeChNiQue. Equal volumes of serum to be tested and a $5 \%$ suspension of standard red cells were incubated for two hours at $37^{\circ} \mathrm{C}$. The red cells were then carefully washed three times in saline and a drop of anti-human-globulin serum was mixed with them on a slide. The slide was then gently rocked and the smear examined for agglutination, if necessary microscopically. The results were not recorded as negative until the slides had been under observation for five minutes. The anti-globulin reagent was controlled against known sensitized cells with each batch of tests. Each serum examined was tested against three D-positive and two D-negative samples of standard cells.

(d) TRYPsin TeChNiQue. A stock solution was made by dissolving $0 \cdot 1 \mathrm{~g}$. of crystalline trypsin (Armour) in $10 \mathrm{ml} . \frac{\mathrm{N}}{20} \mathrm{HCl}$. Each day before use the trypsin solution was diluted 1 in 10 with $0.1 \mathrm{M}$ phosphate buffer at $p \mathrm{H} \mathrm{7 \cdot 7.} \mathrm{This} \mathrm{buffered} \mathrm{enzyme} \mathrm{was} \mathrm{added} \mathrm{to} \mathrm{twice-}$ washed cells of the appropriated $\mathrm{Rh}$ type in the proportion of four parts of solution to one part of packed red cells. (The red cells used for trypsin testing are freshly bled into $3.7 \%$ sodium citrate solution, separated by centrifugation and washed twice with $0.85 \%$ saline.) After adding buffered trypsin solution the red cells were incubated at $37^{\circ} \mathrm{C}$. for 30 minutes, then washed twice in warm saline at $37^{\circ} \mathrm{C}$. Before adding the trypsintreated cells to the test sera a $2-4 \%$ suspension of the cells was made in warm saline. Equal volumes of test serum and trypsinized red cells were incubated for approximately one hour at $37^{\circ} \mathrm{C}$. and the tests read for agglutination. In the case of trypsin tests it is not advisable to handle the cell sediments too gently or false positive results may be obtained. The same standard cells were used for the test as for the indirect Coombs test.

\section{Part I: Titres of Anti-A and Anti-B Isoagglutinins in Colostrum and Milk and Infants' Sera}

Samples were taken from 97 mothers and their babies. Of the mothers, 52 belonged to Group $\mathrm{O}$, 39 to Group A, four to Group B and two to Group AB. The anti-A and anti-B agglutinins were titrated in the maternal serum taken at the time of delivery, in the colostrum on the third day post 
partum and in the milk on the tenth day. The baby's serum was tested for the presence of anti-A and anti-B agglutinins in the cord blood at birth and at the third and tenth days of life. Cases in which the baby was small were not included, nor were those in which breast feeding was unsuccessful.

Results. The titres of anti-A and anti-B agglutinins in the maternal serum ranged from 16 to 1,000 ; in the milk, from 1 to 1,000 ; and in the colostrum, from 2 to 64,000 . In most cases the concentration of agglutinins was higher in colostrum than in milk.

The titres of anti-A and anti-B agglutinins in the infant's serum were low, ranging from 0 to 16 , and the majority of them were less than 8 . The relationship between titres of agglutinins in colostrum and in milk and those in maternal serum and colostrum, and the change of titre in the infant's serum and colostrum, are shown in Figs. 1-3. (In these diagrams the titre is expressed in units of the number of serial dilutions and not in the actual dilution.) These relationships are all in respect of the anti-B agglutinin, because owing to the distribution of $\mathrm{ABO}$ blood groups there are many more cases in which the anti-B agglutinin is compatible with the infant's red cells.

A true picture of the state of affairs with regard to agglutinins that are incompatible with the infant's red cells cannot be obtained owing to absorption of these agglutinins by the infant's tissues and body fluids.

Discussion. Figs. 1 and 2 show that there is some correlation between titres of agglutinins in colostrum and milk and between those of maternal serum and colostrum, the tendency being for women with high serum titres to possess the highest colostrum titres, and also, as might be expected, high colostrum titres

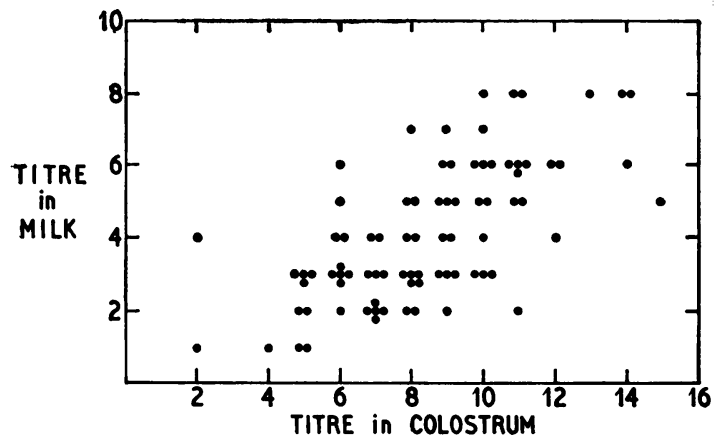

FIG. 1.-Relationship between titres of agglutinins in colostrum and milk. were followed by higher titres of antibody in the milk.

Evidence of an effect of colostrum titre on that of the infant's serum was sought by plotting the

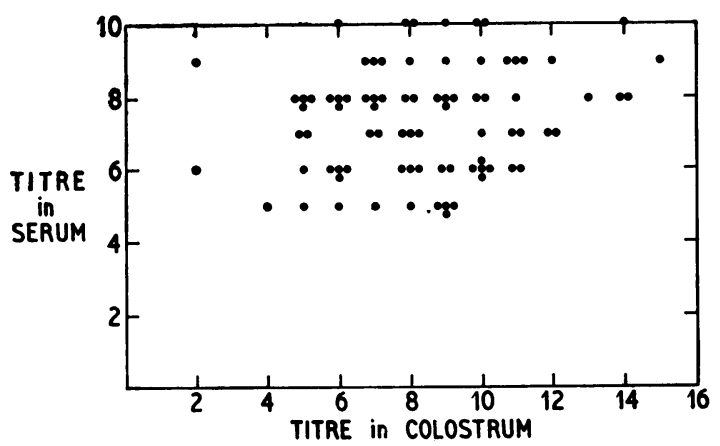

FIG. 2.-Relationship between titres of agglutinins in maternal serum and colostrum.

colostrum titre against the change in titre in the infant's serum between birth and the tenth day (Fig. 3). No significant correlation was found, nor was there any correlation when the titres of milk were similarly plotted.

The range of titre of the agglutinin in colostrum in this group of cases was between 2 and 8,000. Assuming that the effect of dilution would be similar if it were absorbed unchanged, it was thought that some difference in titre in the sera of babies after the ingestion of colostrum with this range of titre variation might be detectable. With complete absorption the dilution in the baby's intravascular fluids would be of the order of one in six for each ounce taken. By the tenth day a baby fully fed from the breast may have received between one-half and two-thirds of its birth weight in colostrum and milk. Even if most of the secretion were milk a substantial absorption of agglutinins might reasonably be expected to be reflected in the infant's serum. The

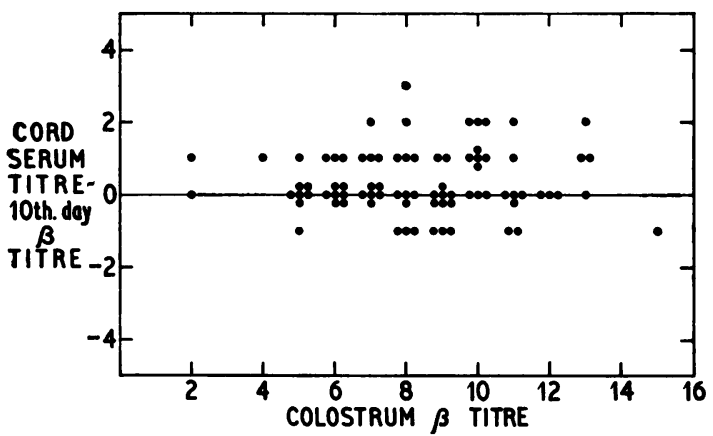

FIG. 3.-Showing effect of colostrum titre on that of infant's serum. 
range of titre in the colostrum and milk was so great that it is unlikely that variations in the amount taken would have obscured evidence of absorption if it had occurred in more than trace amounts.

It is of interest to note that in the cases in which the infant was taking large quantities of incompatible agglutinin with the colostrum and milk, for example, Group A babies of Group $\mathbf{O}$ mothers in some of whom the colostrum titres were $512-4,000$, no sign of jaundice or anaemia was observed in the baby.

The fact that a few infants' sera showed agglutinin titres above 8 seems to indicate that occasionally saline agglutinins as opposed to incomplete antibodies are able to cross the placental barrier and enter the foetal circulation. In the opinion of some workers only incomplete antibodies are capable of this.

The above study of anti-A and anti-B content of maternal serum, milk and colostrum are an early one and a measure of incomplete antibodies was made. Very recently some evidence in a few cases had been obtained for the transfer of incomplete anti-A from mother to milk and from milk to infant (Munk-Anderson, Aagaard and Dyggve, 1957).

\section{Part II: Inhibition of Rh Antibodies by Newborn Babies}

Method. Either milk or serum containing $\mathrm{Rh}$ antibodies of high titre was given by mouth to normal babies. The $\mathrm{Rh}$ type was determined from the cord blood at birth, and feeding of the material was started as soon as possible afterwards. The antibody containing material had been collected from suitable donors and stored at $-18^{\circ}$ C. until required. It was gently warmed to a suitable temperature for the baby, and the residue from each feed was saved and titrated to confirm that the heat had not altered the titration value. The infant's serum was obtained by heel puncture and in every case samples were taken during feeding and approximately daily for two or three days afterwards.

In all, 21 babies were fed with either serum or milk containing Rh antibodies. The first 11 of these were investigated before the introduction of the very sensitive trypsin technique for the detection of incomplete antibodies, and the last 10 cases were investigated with this technique as well as the indirect Coombs technique.

With one exception $\mathrm{Rh}$-negative babies were selected to avoid possible injury to the baby and also to eliminate the risk of antibodies becoming attached specifically to tissue cells and thus not being detectable in the circulation.

Milk containing $\mathrm{Rh}$ antibodies was given to one $\mathrm{Rh}$-negative and one Rh-positive baby, and serum containing $\mathrm{Rh}$-antibodies of both complete and incomplete types was fed to the remaining 19 . Hightitre fluids were deliberately selected in order to obtain the maximum chance of detecting antibody in the infant's circulation if present. The first dose of the material was given as early as possible in life; two babies even received it within two hours of birth. This timing was chosen to test the possibility that absorption in human beings resembles that in ungulates: absorption is almost quantitative in calves and lambs during the first 24 hours, but virtually ceases after 48 hours. The serum was either fed

TABLE

\begin{tabular}{|c|c|c|c|c|c|c|c|c|}
\hline Case No. & $\begin{array}{l}\text { Rhesus } \\
\text { Group }\end{array}$ & $\begin{array}{l}\text { Age of Baby } \\
\text { when Antibody } \\
\text { Received }\end{array}$ & $\begin{array}{l}\text { Material } \\
\text { and Vol } \\
\text { (ml.) }\end{array}$ & $\begin{array}{l}\text { Taken } \\
\text { ame }\end{array}$ & $\begin{array}{l}\text { Titre and } \\
\text { Type of } \\
\text { Antibody }\end{array}$ & $\begin{array}{l}\text { Maximum } \\
\text { Effective } \\
\text { Volume } \\
\text { (litres) }\end{array}$ & $\begin{array}{l}\text { Birth } \\
\text { Weight } \\
\text { (kg.) }\end{array}$ & $\begin{array}{c}\text { Fraction of Dose } \\
\text { Estimated Detectable } \\
\text { in Intravascular } \\
\text { Plasma }\end{array}$ \\
\hline $\begin{array}{r}1 \\
2 \\
3 \\
4 \\
5 \\
6 \\
7 \\
8 \\
9 \\
10 \\
11 \\
12 \\
13 \\
14 \\
15 \\
16 \\
17 \\
18 \\
19 \\
20 \\
21\end{array}$ & 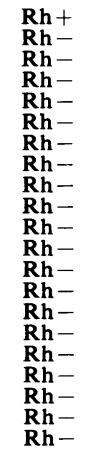 & $\begin{array}{l}4-9 \text { days } \\
12 \text { hrs. }-5 \text { days } \\
12 \text { hrs. }-2 \text { days } \\
12 \text { hrs. }-3 \text { days } \\
2-5 \text { days } \\
18 \text { hrs. }-4 \text { days } \\
11-19 \text { hrs. } \\
12-24 \text { hrs. } \\
12-24 \text { hrs. } \\
2-10 \text { hrs. } \\
2-4 \text { hrs. } \\
13-38 \text { hrs. } \\
15-35 \text { hrs. } \\
17-36 \text { hrs. } \\
15-36 \text { hrs. } \\
10-29 \text { hrs. } \\
27-50 \text { hrs. } \\
53-85 \text { hrs. } \\
36-41 \text { hrs. } \\
3-40 \text { hrs. } \\
8-33 \text { hrs. }\end{array}$ & $\begin{array}{l}\text { Milk } \\
\text { Serum } \\
\text { Serum } \\
\text { Serum } \\
\text { Serum } \\
\text { Milk } \\
\text { Serum } \\
\text { Serum } \\
\text { Serum } \\
\text { Serum } \\
\text { Serum } \\
\text { Serum } \\
\text { Serum } \\
\text { Serum } \\
\text { Serum } \\
\text { Serum } \\
\text { Serum } \\
\text { Serum } \\
\text { Serum } \\
\text { Serum } \\
\text { Serum }\end{array}$ & $\begin{array}{r}278 \\
340 \\
119 \\
153 \\
26 \\
810 \\
17 \\
25 \\
25 \\
17 \\
18 \\
47 \\
18 \\
22 \\
22 \\
20 \\
17 \\
21 \\
12 \\
23 \\
16\end{array}$ & $\begin{array}{r}64 \\
64 \\
16 \\
32 \\
1,000 \\
8 \\
1,000 \text {; saline } \\
1,000 ; \text { saline } \\
1,000 ; \text { saline } \\
2,000 ; \text { saline } \\
2,000 ; \text { saline } \\
1,000 \text {; saline } \\
1,000 ; \text { albumin } \\
512 ; \text { albumin } \\
1,000 ; \text { albumin } \\
512 ; \text { albumin } \\
512 ; \text { albumin } \\
256 \text {; saline } \\
512 ; \text { albumin } \\
256 ; \text { saline } \\
512 \text {; albumin }\end{array}$ & $\begin{array}{r}26 \\
16 \\
2 \\
6 \\
27 \\
3 \\
17 \\
25 \\
25 \\
34 \\
36 \\
47 \\
18 \\
10 \\
22 \\
8 \\
8 \\
5 \\
6 \\
5 \\
8\end{array}$ & $\begin{array}{l}3 \cdot 71 \\
3 \cdot 97 \\
2 \cdot 79 \\
3 \cdot 09 \\
3 \cdot 69 \\
3 \cdot 00 \\
4 \cdot 17 \\
3 \cdot 32 \\
3 \cdot 00 \\
4 \cdot 03 \\
3 \cdot 74 \\
3 \cdot 44 \\
3 \cdot 64 \\
3 \cdot 34 \\
3 \cdot 05 \\
3 \cdot 05 \\
3 \cdot 76 \\
3 \cdot 10 \\
3 \cdot 08 \\
3 \cdot 60 \\
3 \cdot 40\end{array}$ & $\begin{array}{l}1 \text { in } 40 \\
1 \text { in } 80 \\
1 \text { in } 13 \\
1 \text { in } 40 \\
1 \text { in } 140 \\
1 \text { in } 20 \\
1 \text { in } 82 \\
1 \text { in } 150 \\
1 \text { in } 166 \\
1 \text { in } 170 \\
1 \text { in } 194 \\
1 \text { in } 273 \\
1 \text { in } 100 \\
1 \text { in } 61 \\
1 \text { in } 44 \\
1 \text { in } 52 \\
1 \text { in } 43 \\
1 \text { in } 32 \\
1 \text { in } 39 \\
1 \text { in } 28 \\
1 \text { in } 47\end{array}$ \\
\hline
\end{tabular}


mixed with measured amounts of fresh colostrum, or given immediately after the feed from the breast in eight cases in order that the antitryptic effect of colostrum or any other unsuspected factor which might assist in antibody absorption might play its physiological rôle.

Results. The accompanying Table gives the volume and titre of the material and the time it was given, together with the birth weight of the baby. Some measure is needed to show what proportion of the antibody would have to be absorbed in order to be detected, although an estimation of this kind can be only approximate. From this it will be assumed that the material, if absorbed unaltered, dispersed round the body, and when obtained in serum from a heel prick would agglutinate cells at a final dilution corresponding to that in the original serum. This leaves no allowance for any "carryover' effect in the original titration. If the number of millilitres of each dose of material is multiplied by the highest dilution at which agglutination is obtained, the sum of all the products for all the doses given to one baby amounts to a volume to which the entire dose might be diluted and still be detectable. If this hypothetical effective volume is compared with the baby's intravascular fluid volume a proportion is obtained which shows very roughly how much of the dose would have to be absorbed to be detectable. These findings are also summarized in the Table, which gives the hypothetical effective volume and its relation to the baby's intravascular fluid. In no case were $\mathrm{Rh}$ antibodies detected in the serum after the infant had been fed with milk or serum containing these antibodies in high titre. In the first 11 cases tests were made by saline and indirect Coombs techniques, using red cells from individuals homozygous for antigen $D$ as well as $R h$-negative cells as a negative control. In the last 10 cases tests by the trypsin technique were also included, since in some instances it has been shown that this technique will reveal the presence of antibodies when other techniques fail.

Discussion. The volume of milk or serum fed to the babies was necessarily less than the amount of milk a baby obtains by suckling, but the titre of the material was very much higher than the titres commonly found in the breast secretion of women with antibodies. In the course of the search for colostrum and milk with $\mathrm{Rh}$ antibodies of high titre many samples were examined. The milk eventually obtained and used for feeding was of exceptionally high titre.

If one may assume that antibodies of high titre, when diluted, are comparable to weak ones, the amounts of antibodies received by the babies were within the range of doses commonly transferred by suckling in the first days of life. It is, however, possible that the absorption of antibodies from colostrum might be different from absorption from serum since, for instance, colostrum contains trypsin inhibitors (Laskowski and Laskowski, 1951).

Antibodies, if absorbed, would be detectable only if the rate of their destruction or removal were relatively slow. The rate of disappearance of other passive immune bodies has been found to extend over weeks rather than days (Barr, Glenny and Randall, 1949). This slow rate was confirmed in the present investigation by studying the fall in titre in babies' sera. Two babies, the unaffected children of mothers with $R h$ antibodies from previous sensitization, received $\mathrm{Rh}$ antibodies transplacentally. These remained detectable for two weeks. Two were given antibody intravenously and the rate of disappearance of the antibody in these two cases is given in Fig. 4. It is concluded that the negative

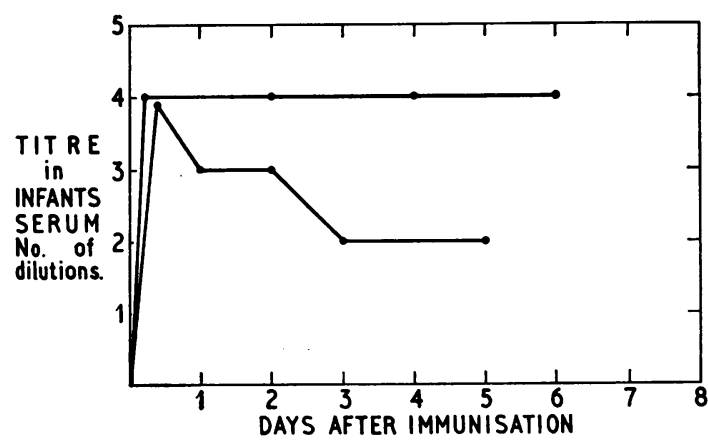

FIG. 4.- Showing rate of disappearance of antibody given intravenously to two babies.

result of the tests for absorbed agglutinins was not attributable to quick removal of the antibody or to ill timing of the sampling of the infant's serum.

Cathie (1947) also found no evidence of absorption of unaltered antibodies. His material was given to Rh-positive individuals, one man and several children, the youngest apparently being 1 week old. He concluded that there was no justification for weaning infants with haemolytic disease on account of the presence of $\mathrm{Rh}$ antibodies in the breast milk. Since his subjects were $R h$ positive there was a likelihood that if partial absorption occurred, the antibodies might become attached to tissues without becoming detectable in the serum. The dosage given in the present investigation and the fact that the subjects were $R h$ negative are believed to have ensured that if even only a small 
proportion of the antibody given were absorbed it would have been detected. The fact that no absorbed antibody was found in the infant's serum is not regarded as conclusive evidence that $R h$-positive babies of mothers with $\mathrm{Rh}$ antibodies may be fed from the breast during the first days of life. It seems undesirable to give a baby, whether mildly or severely affected with haemolytic disease, more of the one substance from which it is suffering. The mechanism, whether it is intestinal juice, gut wall or liver, which prevents free absorption is unknown; nor is it known whether the mechanism is injured in affected babies. Since affected babies are nearly always the offspring of multiparae, the maintenance of lactation without putting the baby to the breast is usually practicable for the seven or eight days until the agglutinin titre of the milk has fallen. During this time expressed milk may be boiled and given to the baby, and direct feeding started on the eighth day.

The slow elimination of passive immune bodies and the range of dosage used in this investigation still leave a possibility that a baby could slowly accumulate rather than lose antibodies although no absorption has been detected. The protection afforded by breast milk against measles (Douglas) already mentioned hints that this is so. It is therefore recommended that a baby born with cells sensitized by $R h$ agglutinins should be fed from the breast after eight days and fed with heated expressed breast milk until then. Moreover, since we have not been able to demonstrate the transfer of antibodies from milk and colostrum to the infant, there is no reason to suppose that by heating the breast milk the baby is being deprived of other kinds of antibody which are beneficial.

\section{Summary}

Part I. Samples of serum, colostrum and milk from 97 mothers and their infants were tested for their anti-A and anti-B content.

The titres of anti-A and anti-B agglutinins in the maternal serum ranged from 16 to 1,000 , in the milk from 1 to 1,000 , in the colostrum from 2 to 64,000 and in the infant's serum from 0 to 16 . Some correlation was noted between titres of agglutinins in colostrum and milk and between those of maternal serum and colostrum. No correlation was established between titres of colostrum or milk and the infants' serum.

Part II. Serum and milk containing $\mathrm{Rh}$ antibodies were given to one $\mathrm{Rh}$-positive and 20 $R h$-negative infants in the first days of life.

The infants' sera were tested for Rh antibodies by saline and indirect Coombs techniques in the first 11 cases, and by saline, indirect Coombs and trypsin techniques in the last 10 cases. No Rh antibodies were detected.

The material given would have been detectable after dilution in the baby's intravascular fluid if approximately one in 150 parts was absorbed unaltered.

The material was given to some babies within 24 hours of birth. Absorption comparable to that which occurs in ungulates immediately after birth was not found.

The sensitivity of the methods used does not preclude absorption of traces of unaltered antibodies by babies already affected by $\mathrm{Rh}$ antibodies. Expression and heat treatment of breast milk during the first eight days is recommended where the baby's cells are sensitized.

Our thanks are due to Dr. J. F. Loutit, Dr. R. A. Zeitlin and Miss Doreen Daley for their help and cooperation in this work, most of which was carried out while we were employed by the Medical Research Council.

\section{REFERENCES}

Barr, M., Glenny, A. T. and Randall, K. J. (1949). Lancet, 2, 324. Cathie, I. A. B. (1947). Brit. med. J., 2, 650

Douglas, J. W. B. (1950). J. Obstet." Gynaec. Brit. Emp., 57, 335. Ehrlich, P. (1892). Z. Hyg. Infekt.-Kr. 12, 183.

Hirszfeld, L. and Lille-Szyszkowicz, J. (1949). Rev. Immunol. (Paris), 13, 265.

Laskowski, M., Jr., Laskowski, M. (1951). J. biol. Chem., 190, 563. Mason, J. H., Dalling, T. and Gordon, W. S. (1930). J. Path. Bact., $33,783$.

Munk-Anderson, G., Aagaard, K. and Dyggve, H. (1957) VI Congress of the European Society of Haematology Abstracts. p. 153.

Rimington, C. and Bickford, J. A. (1946). Biochem. J., 40, xxvi. Taylor, G. L. and Ikin, E. W. (1939). Brit. med. J., 1, 1027. 